\title{
Camphoratins A-J, Potent Cytotoxic and Anti-inflammatory Triterpenoids from the Fruiting Body of Taiwanofungus camphoratus
}

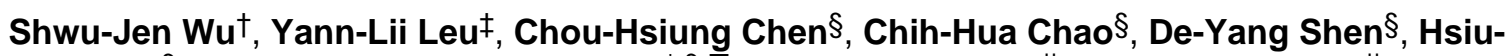 \\ Hui Chan $\S$, E-Jian Lee ${ }^{\perp}$, Tian-Shung Wu ${ }^{\star}, \S, \nabla,+$, Yea-Hwey Wang $\|$, Yuh-Chiang Shen ${ }^{\|,+}$, \\ Keduo Qian ${ }^{\circ}$, Kenneth F. Bastow ${ }^{\circ}$, and Kuo-Hsiung Lee ${ }^{\star}, \nabla,{ }^{\circ}$ \\ Department of Medical Technology, Chung Hua University of Medical Technology, Tainan 717, \\ Taiwan, Natural Products Laboratory, Graduate Institute of Natural Products, Chang Gung \\ University, Kweishan, Taoyuan 333, Taiwan, Department of Chemistry, National Cheng Kung \\ University, Tainan 701, Taiwan, Neurophysiology Laboratory, Neurosurgical Service, Department \\ of Surgery, National Cheng Kung University Medical Center and Medical School, Tainan, Taiwan, \\ College of Pharmacy, China Medical University, Taichung, Taiwan 401, National Research \\ Institute of Chinese Medicine, Taipei 112, Taiwan, Chinese Medicine Research and Development \\ Center, China Medical University and Hospital, Taichung, Taiwan Natural Products Research \\ Laboratories, Division of Medicinal Chemistry and Natural Products, Eshelman School of \\ Pharmacy, University of North Carolina, Chapel Hill, North Carolina 27599-7568, USA
}

\begin{abstract}
Ten new triterpenoids, camphoratins A-J (1-10), along with 12 known compounds were isolated from the fruiting body of Taiwanofungus camphoratus. Their structures were established by spectroscopic analysis and chemical methods. Compound $\mathbf{1 0}$ is the first example of a naturally occurring ergosteroid with an unusual cis-C/D ring junction. Compounds 2-6 and $\mathbf{1 1}$ showed moderate to potent cytotoxicity with $\mathrm{EC}_{50}$ values ranging from 0.3 to $3 \mu \mathrm{M}$ against $\mathrm{KB}$ and $\mathrm{KB}$ VIN human cancer cell lines. Compounds 6, 10, 11, 14-16, 18, and 21 exhibited antiinflammatory NO-production inhibition activity with $\mathrm{IC}_{50}$ values of less than $5 \mu \mathrm{M}$, which was more potent than the nonspecific NOS inhibitor $N^{\omega}$-nitro-L-arginine methyl ester (L-NAME).
\end{abstract}

Taiwanofungus camphoratus (synonym: Ganoderma camphoratum; Antrodia cinnamomea; Antrodia camphorata) (Polyporaceae, Aphyllophorales), is a rare and precious medical fungus in Taiwan and is called a "national treasure of Taiwan".1 Its Chinese name is Zhan$\mathrm{Ku}$ or Niu-Chang-Chih. The microorganism is parasitic to the inner heart-wood wall of old hollow trunks of Cinnamomum kanehirai Hay. (Lauraceae). The growth rate of natural $T$. camphoratus in the wild is very slow, and it is difficult to cultivate in a greenhouse, making fruiting bodies expensive to obtain. In traditional Taiwanese folk medicine T. camphoratus has been used as an important health food for treating food, alcohol, and drug intoxication,

\footnotetext{
*Corresponding authors: Tel: 919-962-0066. Fax: 919-966-3893. khlee@ unc.edu; tswu@ mail.ncku.edu.tw.

†Chung Hua University of Medical Technology.

\$Chang Gung University.

$\S$ Department of Chemistry, National Cheng Kung University.

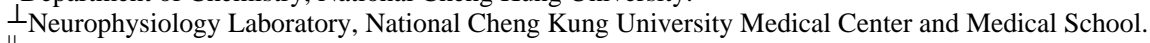

$\|_{\text {National Research Institute of Chinese Medicine. }}$

$\nabla_{\text {China Medical University and Hospital. }}$

${ }^{\circ}$ University of North Carolina.

${ }^{+}$These authors contributed equally to this work.

Supporting Information Available. ${ }^{1} \mathrm{H}$ and ${ }^{13} \mathrm{C}$ NMR spectra of 1-10 are available free of charge via the Internet at http://pubs.acs.org.
} 
diarrhea, abdominal pain, hypertension, itching, and liver cancer.2 Previous studies on the chemical constituents of the fruiting body of $T$. camphoratus showed that it is a rich source of triterpenoidic acids, some of which have shown anti-inflammatory, 3 anticholinergic, 4 and antiserotonergic activities.4 Furthermore, zhankuic acids $\mathrm{A}$ and $\mathrm{C}$ exhibited significant cytotoxicity against P-388 murine leukemia cells in vitro. 4 The present study on the chemical constituents of an EtOH extract of the fruiting body of T. camphoratus has led to the isolation of 10 new triterpenoids, namely camphoratins A-J (1-10), and 12 known compounds, including zhankuic acids A-C (11-13),4,5 zhankuic acid A methyl ester (14),4 antcin A (15),5 antcin C (16),5 antcin K (17),6 methyl antcinate $\mathrm{H}(\mathbf{1 8}), 7$ eburicol (19), 8 ergosterol D (20),9 methyl 4 $\alpha$-methylergost-8,24(28)-diene-3,11-dion-26-oate (21),10 and ergosterol peroxide (22).11 Cytotoxic activity, inhibition of nitric oxide (NO) or reactive oxygen species (ROS) production, and free radical-scavenging activity of the isolates were evaluated in our study.

\section{Results and Discussion}

Camphoratin A (1) was obtained as a colorless powder. The HRESIMS of 1 showed a pseudomolecular ion peak at $\mathrm{m} / \mathrm{z} 511.3038$, consistent with a molecular formula of $\mathrm{C}_{29} \mathrm{H}_{44} \mathrm{O}_{6} \mathrm{Na}$, and eight degrees of unsaturation. The UV and IR absorption bands at $255 \mathrm{~nm}$ and 1709,1660 , and $3408 \mathrm{~cm}^{-1}$, respectively, suggested the presence of $\alpha, \beta$-unsaturated carbonyl and carboxylic acid functionalities. The former was corroborated by carbon resonances at $\delta 202.8(\mathrm{qC}), 154.3(\mathrm{qC})$, and $141.2(\mathrm{qC})$, and the latter was evidenced by the resonance at $\delta 176.9(\mathrm{qC})$. An exocyclic double bond was also identified from the NMR signals at $\delta_{\mathrm{C}} 150.7(\mathrm{qC}), 110.5\left(\mathrm{CH}_{2}\right)$ and $\delta_{\mathrm{H}} 5.07,5.23$ (each $\left.1 \mathrm{H}, \mathrm{s}\right)$. The above data, coupled with the characteristic methyl signals at $\delta_{\mathrm{H}} 0.90(3 \mathrm{H}, \mathrm{s}), 1.11(3 \mathrm{H}, \mathrm{d}, J=7.6 \mathrm{~Hz})$, $1.18(3 \mathrm{H}, \mathrm{d}, J=6.8 \mathrm{~Hz}), 1.48(3 \mathrm{H}, \mathrm{d}, J=7.2 \mathrm{~Hz})$, and $1.57(3 \mathrm{H}, \mathrm{s})$, suggested a 4-methylergost-8-en-11-one skeleton similar to that of antcin C (16).5 The $3 \alpha-\mathrm{OH}$ functionality was deduced by the correlations from $\mathrm{H}-3(\delta 3.89,1 \mathrm{H}, \mathrm{d}, J=1.6 \mathrm{~Hz}, \beta$-orientation) to C-4 and $\mathrm{C}-1$ and from $\mathrm{H}_{3}-29$ to $\mathrm{C}-3, \mathrm{C}-4$, and $\mathrm{C}-5$ in the HMBC spectrum of $\mathbf{1}$. The hydroxy groups attached at C-7 and C-12 were further designated by the correlations from $\mathrm{H}-7(\delta 4.52,1 \mathrm{H}, \mathrm{t}$, $J=8.4 \mathrm{~Hz})$ to C-6 and C-8 and from H-12 $(4.44,1 \mathrm{H}, \mathrm{s})$ to C-13, C-14, and C-17, respectively. The $\mathrm{C}-25$ carboxylic functionality was assigned due to the presence of an HMBC correlation from H-25 $(\delta 3.45,1 \mathrm{H}, \mathrm{q}, J=6.8 \mathrm{~Hz})$ to the carbon resonance at $\delta 176.9$. A comparison of the NMR spectroscopic data of 1 with those of 165 confirmed the above elucidation and unambiguously established the structure of $\mathbf{1}$. The relative configuration of 1 was determined by the NOE correlations observed in a NOESY experiment. In the NOESY spectrum of 1, H-7 showed NOE enhancements with both H-5 and H-14, suggesting that these protons had $\alpha$-orientations. Furthermore, NOE correlations between H-3 and H- 4 as well as between $\mathrm{H}-12$ and $\mathrm{H}_{3}-18$ disclosed that these protons are $\beta$-oriented.

Camphoratin B (2) was obtained as a colorless syrup. The HRESIMS of 2 gave an [M + $\mathrm{Na}]^{+}$peak at $\mathrm{m} / z 495.3089$ and established the molecular formula $\mathrm{C}_{29} \mathrm{H}_{44} \mathrm{O}_{5} \mathrm{Na}$, which is 16 mass units less than that of $\mathbf{1}$. The ${ }^{1} \mathrm{H}$ NMR and ${ }^{13} \mathrm{C}$ NMR spectroscopic data of $\mathbf{2}$ were similar to those of $\mathbf{1 6}$ except for the presence of a $3 \alpha-\mathrm{OH}$ in $\mathbf{2}$ rather than a carbonyl group in 16. The data were also similar to those of $\mathbf{1}$ except that the hydroxy-containing methine (C-12) in $\mathbf{1}$ was replaced by a methylene group in $\mathbf{2}$. This assignment was confirmed by the significant up-field shift of $\mathrm{H}-14(\delta 2.66,1 \mathrm{H}, \mathrm{dd}, J=12.0,6.0 \mathrm{~Hz})$ in 2 , relative to that in 1 $(\delta 3.57,1 \mathrm{H}, \mathrm{dd}, J=12.0,6.8 \mathrm{~Hz}$ ), due to the absence of a quasi 1,3-diaxial interaction between $\mathrm{H}-14$ and $12 \alpha-\mathrm{OH}$. In addition, the HMBC correlations from $\mathrm{H}_{2}-12$ to $\mathrm{C}-11, \mathrm{C}-13$, C-14, and C-18 further demonstrated the above elucidations.

Camphoratin $\mathrm{C}(\mathbf{3})$ was obtained as a colorless powder and was found to possess the molecular formula, $\mathrm{C}_{29} \mathrm{H}_{42} \mathrm{O}_{6} \mathrm{Na}$, as deduced from the HRESIMS and NMR data. Its IR 
spectrum showed the presence of hydroxy $\left(3411 \mathrm{~cm}^{-1}\right)$, carboxylic acid $\left(1707 \mathrm{~cm}^{-1}\right)$, and conjugated carbonyl $\left(1674 \mathrm{~cm}^{-1}\right)$ groups. The UV spectrum showed similar absorption bands to those of 11-13,4 which indicated the presence of an 8(9)-en-7,11-dione moiety. This assignment was further corroborated by the carbon resonances at $\delta 203.05$ (qC), 203.0 (qC), $155.0(\mathrm{qC})$, and $144.2(\mathrm{qC})$. A comparison of NMR spectroscopic data of $\mathbf{3}$ with those of $\mathbf{1 7 6}$ revealed identical substitution at C-3 and C-4, while the C-7 hydroxy group in $\mathbf{1 7}$ was oxidized to a carbonyl moiety in $\mathbf{3}$.

Camphoratin D (4) was isolated as a colorless powder and exhibited an $[\mathrm{M}+\mathrm{Na}]^{+}$peak at $m / z 509.2875$, corresponding to a molecular formula of $\mathrm{C}_{29} \mathrm{H}_{42} \mathrm{O}_{6} \mathrm{Na}$ as obtained from HRESIMS. Its IR spectrum showed the presence of hydroxy $\left(3444 \mathrm{~cm}^{-1}\right)$, carbonyl (1708 $\left.\mathrm{cm}^{-1}\right)$, and conjugated ketone $\left(1674 \mathrm{~cm}^{-1}\right)$ groups. The UV spectrum showed absorption bands at $246 \mathrm{~nm}$, suggesting the presence of an 8(9)-en-11-one moiety,5 which was corroborated by the carbon resonances at $\delta 199.5(\mathrm{qC}), 154.3(\mathrm{qC})$, and $141.2(\mathrm{qC})$. The proton resonance at $\delta 4.98(1 \mathrm{H}, \mathrm{t}, J=8.4 \mathrm{~Hz})$ was attributed to the $7 \beta$ hydroxy functionality. The other carbonyl carbon resonance at $\delta 211.0$ was assigned to $\mathrm{C}-3$ due to the observation of $\mathrm{HMBC}$ correlations from $\mathrm{H}_{3}-29$ to $\mathrm{C}-3, \mathrm{C}-4$, and C-5. The side chain moiety was found to be the same as that in 1-3. Moreover, a hydroxy-containing quaternary carbon was assigned at $\mathrm{C}-14$ according to the downfield shift of $\mathrm{C}-15$ as compared to the corresponding carbon in 1-3. In the ${ }^{13} \mathrm{C}$ NMR spectrum of $\mathbf{4}$, the significant upfield shift for C-12 $(\Delta=-9.4 \mathrm{ppm})$ and $\mathrm{C}-17(\Delta=-5.5 \mathrm{ppm})$ as well as the downfield shift for $\mathrm{C}-18(\Delta=+3.9 \mathrm{ppm})$, relative to those in $2(\mathrm{C}-12, \delta 58.9 ; \mathrm{C}-17, \delta 55.0)$, suggested an $\alpha$-orientation for $14-\mathrm{OH} .7,12$

Camphoratin E (5), a colorless syrup, was found to possess the molecular formula $\mathrm{C}_{30} \mathrm{H}_{44} \mathrm{O}_{5}$, as deduced from the HRESIMS and NMR spectroscopic data. Its IR spectrum showed the presence of hydroxy $\left(3491 \mathrm{~cm}^{-1}\right)$, ester $\left(1730 \mathrm{~cm}^{-1}\right)$, and conjugated carbonyl $\left(1678 \mathrm{~cm}^{-1}\right)$ groups. The UV absorption band at $v_{\max } 260 \mathrm{~nm}$ and carbon resonances at $\delta$ 203.1 (qC), 202.1 (qC), 153.7 (qC), and 144.7 (qC) indicated the presence of an 8(9)ene-7,11-dione moiety. The NMR spectroscopic data of $\mathbf{5}$ were similar to those of $\mathbf{1 2 4}$ except for additional methoxy signals at $\delta_{\mathrm{H}} 3.66$ and $\delta_{\mathrm{C}} 51.9$, which suggested that $\mathbf{5}$ is the methyl ester of $\mathbf{1 2}$. In the ${ }^{13} \mathrm{C}$ NMR spectra of $\mathbf{5}$, several smaller signals at $\delta_{\mathrm{C}} 31.0,45.5$, and 16.3 revealed the presence of an epimeric mixture at C-25.4

The HRESIMS of camphoratin F (6) established the same molecular formula, $\mathrm{C}_{30} \mathrm{H}_{44} \mathrm{O}_{5}$, as that of 5. Its UV and IR spectra showed the presence of an 8(9)-en-11-one moiety ( $\lambda_{\max } 251$ $\mathrm{nm}$ and $\left.v_{\max } 1669 \mathrm{~cm}^{-1}\right)$, a carbonyl group $\left(1711 \mathrm{~cm}^{-1}\right)$, and an ester moiety $\left(1735 \mathrm{~cm}^{-1}\right)$. Comparison of the NMR data of $\mathbf{6}$ and $\mathbf{5}$ showed that the hydroxy-linked methine resonance of H-3 in $\mathbf{5}$ was absent from the NMR spectrum of $\mathbf{6}$, and replaced by a carbonyl functionality at $\delta_{\mathrm{C}} 212.3$. In addition, the carbon resonance for the C-7 carbonyl group in 5 was converted to a hydroxy-linked methine $\left(\delta_{\mathrm{H}} 4.39,1 \mathrm{H}, \mathrm{t}, J=8.0 \mathrm{~Hz}\right)$ in $\mathbf{6}$. A $\beta$-orientation of the hydroxy group at C-7 was deduced by the splitting pattern of $\mathrm{H}-7$ as compared to those in $\mathbf{1}$ and $\mathbf{2}$. Similarly to $\mathbf{5}$, the NMR data of $\mathbf{6}$ showed the presence of an epimeric mixture at C-25 (Table 1).

Camphoratin $\mathrm{G}$ (7) was found to have the molecular formula $\mathrm{C}_{29} \mathrm{H}_{42} \mathrm{O}_{5}, 14$ mass units less than $\mathbf{6}$, as deduced from the HRESIMS and NMR data. The UV and IR spectra of $\mathbf{7}$ were similar to those of 6, except that a carboxylic acid moiety was observed in $7\left(v_{\max } 1707\right.$ $\mathrm{cm}^{-1}$ ) rather than an ester group. Consequently, the structure of $\mathbf{7}$ might be structurally related to 6 . Comparison of ${ }^{1} \mathrm{H}$ NMR data of $\mathbf{7}$ with those of $\mathbf{6}$, antcin $\mathrm{F}$, and methyl antcinate G,7 disclosed that 7 might be a C-7 epimer of antcin F. Moreover, the splitting pattern of $\mathrm{H}-7(\mathrm{~d}, J=2.0 \mathrm{~Hz})$ in 7 suggested a $\beta$-oriented proton7 rather than an $\alpha$-proton like those in $\mathbf{1}, \mathbf{2}$, and $\mathbf{6}$. 
The HRESIMS of camphoratin $\mathrm{H}(\mathbf{8})$ gave a pseudomolecular ion peak at $\mathrm{m} / \mathrm{z} 447.3237$ [M $+\mathrm{Na}]^{+}$, corresponding to the molecular formula $\mathrm{C}_{29} \mathrm{H}_{44} \mathrm{O}_{2} \mathrm{Na}$. Its UV and IR spectra showed the presence of an 8(9)-en-11-one moiety $\left(\lambda_{\max } 248 \mathrm{~nm}\right.$ and $\left.v_{\max } 1678 \mathrm{~cm}^{-1}\right)$ and a carbonyl group $\left(1711 \mathrm{~cm}^{-1}\right)$. Its ${ }^{1} \mathrm{H}$ NMR spectrum displayed signals for six methyl groups at $\delta_{\mathrm{H}} 0.74$ (s), 0.95 (d), 1.03 (d), 1.06 (d), 1.29 (d), and 1.34 (s). The above data coupled with the absence of the carbon resonance appropriate for a carboxylic acid or a methyl ester moiety suggested that $\mathbf{8}$ possesses a 4-methyl-ergost-8-en-11-one skeleton. The NMR spectra of $\mathbf{8}$ were similar to those of $\mathbf{1 5}, 5$ except that the NMR signals appropriate for a carboxylic functionality were replaced by signals for a C-25 methyl group.

Camphoratin I (9) was found to have the molecular formula $\mathrm{C}_{28} \mathrm{H}_{44} \mathrm{O}_{2}$ from HRESIMS analysis. The absence of UV absorption bands from 240 to $270 \mathrm{~nm}$ disclosed that $9 \mathrm{did}$ not possess an 8(9)-en-7,11-dione or 8(9)-en-11-one moiety. The IR and ${ }^{13} \mathrm{C}$ NMR data of 9 showed the presence of 28 carbon signals, including one carbonyl group $\left(\delta 211.9, v_{\max } 1716\right.$ $\left.\mathrm{cm}^{-1}\right)$, two double bonds $(\delta 139.4,117.1,136.7$, and 130.4$)$, and one hydroxymethyl moiety $\left(\delta 66.9, v_{\max } 3336 \mathrm{~cm}^{-1}\right)$. The above data, coupled with the characteristic methyl signals at $\delta_{\mathrm{H}} 0.57(3 \mathrm{H}, \mathrm{s}), 0.86(3 \mathrm{H}, \mathrm{d}, J=6.8 \mathrm{~Hz}), 1.00(3 \mathrm{H}, \mathrm{d}, J=6.8 \mathrm{~Hz}), 1.01(3 \mathrm{H}, \mathrm{s})$, and 1.02 $(3 \mathrm{H}, \mathrm{d}, J=7.2 \mathrm{~Hz})$, suggested that 9 is similar to the known compound ergost-7-en-3-one.13 By comparison of the ${ }^{13} \mathrm{C}$ NMR spectroscopic data of 9 with those of ergost-7-en-3-one, it was found that resonances for the nucleus of both compounds were superimposable, revealing that they have different substitution patterns in the side chain moiety. This was confirmed by the $\mathrm{HMBC}$ correlations from $\mathrm{H}_{3}-21$ to $\mathrm{C}-17, \mathrm{C}-20$, and C-22, from $\mathrm{H}_{3}-28$ to $\mathrm{C}-23, \mathrm{C}-24$, and $\mathrm{C}-25$, and from $\mathrm{H}_{3}-27$ to $\mathrm{C}-24, \mathrm{C}-25$, and $\mathrm{C}-26$. Comparison of the NMR data of C-24, C27, and C-28 of 9 with those of synthetic compounds led to the establishment of an erythro configuration at C-24 and C-25 $(24 S, 25 S$ or $24 R, 25 R)$. Furthermore, the $24 S$, $25 S$ configuration for 9 was confirmed by the preparation of its $(R)$-MTPA ester, in which the proton resonance of $\mathrm{H}_{2}-26$ showed a broad doublet at $\delta$ 4.17.14 In addition, the MTPA ester helped to establish the $E$ geometry of C-22-C-23 double bond by a $15.0 \mathrm{~Hz}$ coupling constant.

The molecular formula of camphoratin $\mathbf{J}(\mathbf{1 0})$ was assigned as $\mathrm{C}_{30} \mathrm{H}_{44} \mathrm{O}_{4}$ based on its HRESIMS. Its UV and IR spectra showed the presence of an 8(9)-en-11-one moiety ( $\lambda_{\max }$ $250 \mathrm{~nm}$ and $\left.v_{\max } 1669 \mathrm{~cm}^{-1}\right)$, a carbonyl group $\left(1709 \mathrm{~cm}^{-1}\right)$, and an ester moiety $(1738$ $\mathrm{cm}^{-1}$ ). The 8(9)-en-11-one moiety was deduced by the carbon resonances at $\delta 200.4,138.0$, and 154.6 and $\mathrm{HMBC}$ correlations from $\mathrm{H}_{2}-12$ to the carbonyl carbon. The carbonyl and methyl ester functionalities were assigned at C-3 and C-25, respectively, based on the HMBC correlations from $\mathrm{H}_{3}-29$ to C-3, C-4, and C-5 and from $\mathrm{H}-25$ to the carbon resonance at $\delta 175.0$, which was also correlated with the methoxy group at $\delta_{\mathrm{H}} 3.66(3 \mathrm{H}, \mathrm{s})$. The inspection of the 2D NMR spectra led to the establishment of the same planar structure as the known compound methyl $4 \alpha$-methylergost-8,24(28)-diene-3,11-dion-26-oate.10 However, both compounds differed in carbon resonances for rings $\mathrm{C}$ and $\mathrm{D}$, revealing the presence of epimers at the $\mathrm{C} / \mathrm{D}$ ring junction. The relative configuration of the $\mathrm{C} / \mathrm{D}$ ring junction in $\mathbf{1 0}$ was elucidated by the NOE enhancements observed in a selective 1D NOESY experiment. Irradiation of $\mathrm{H}_{3}-18$ caused enhancements of $\mathrm{H}-14, \mathrm{H}-20$, and $\mathrm{H}_{3}-21$, but not of $\mathrm{H}-17$, suggesting a cis-fused C/D ring. The downfield shift $(\Delta=+10.4 \mathrm{ppm})$ of C-18 in the ${ }^{13} \mathrm{C}$ NMR spectrum of $\mathbf{1 0}$, relative to that observed for methyl $4 \alpha-$ methylergost-8,24(28)-dien-3,11-dion-26-oate, was also in agreement with a rare cis C/D ring junction, which has been found in compounds from marine sponges.15-17 Additional smaller carbon signals at $\delta_{\mathrm{C}} 31.8,45.5$, and 16.3 were attributed to the other $\mathrm{C}-25$ epimer. Compound 10 represents the first ergosteroid with cis-fused C/D ring junction.

The cytotoxicity of the new and known compounds (1-19) was evaluated in parallel with etoposide against the human cancer cell line KB and multidrug-resistant strain KB-VIN in 
vitro (Table 4). Several of the compounds, including 2-7, 11-13, and 15, showed moderate to potent cytotoxic activity with $\mathrm{EC}_{50}$ values ranging from 0.3 to $15.5 \mu \mathrm{M}$. Compounds 3 and 5 showed the highest cytotoxicity against the $\mathrm{KB}$ cell line with $\mathrm{EC}_{50}$ values of 0.3 and $0.45 \mu \mathrm{M}$, respectively. Compounds $\mathbf{4}$ and $\mathbf{6}$ also showed cytotoxicity against $\mathrm{KB}$ with $\mathrm{EC}_{50}$ values of 1.0 and $2.0 \mu \mathrm{M}$, respectively. More importantly, compounds $\mathbf{4}$ and $\mathbf{6}$ retained their activity against multi-resistant strain $\mathrm{KB}-\mathrm{VIN}$ with $\mathrm{EC}_{50}$ values of 1.4 and $2.9 \mu \mathrm{M}$, respectively. It appeared that $\mathbf{4}$ and $\mathbf{6}$ were not substrates of P-glycoprotein (P-gp), a key transporter related to drug-resistance, based on the lack of cross-resistance shown by KBVIN. By comparison, etoposide, a known P-gp substrate, was at least eight-fold less active in the KB-VIN cell line. Comparing the structures of compounds 3-6, we find that $\mathbf{3}$ and $\mathbf{5}$ contain the same C-3 $\alpha$-hydroxy group and C-7 keto moiety, while $\mathbf{4}$ and $\mathbf{6}$ contain a C-3 keto and C-7 $\beta$-hydroxy group. It seems that the latter triterpene scaffold may overcome the resistance issue. Compound $\mathbf{3}$ has an additional C-4 $\beta$-hydroxy group and a free carboxylic acid tail in its $\mathrm{R}_{5}$ moiety, which may contribute to the best activity profile of the series.

The anti-inflammatory activities of $\mathbf{2}, \mathbf{6}, \mathbf{9}$, and 10-22 were evaluated by examining their effects on lipopolysaccharide (LPS)-induced inducible-nitric oxide synthase (iNOS)dependent NO production and NADPH oxidase (NOX)-dependent ROS production in murine microglial cells (BV2) and peripheral human neutrophils (PMN). Compounds 6, 10, 11, 14-16, 18, and 21 significantly inhibited NOS activity with $\mathrm{IC}_{50}$ values of 2.5, 1.6, 3.6, $0.6,4.1,4.2,2.5$, and $1.5 \mu \mathrm{M}$, respectively. They were more potent than $N^{\omega}$-nitro-L-arginine methyl ester (L-NAME) $\left(\mathrm{IC}_{50} 25.8 \mu \mathrm{M}\right)$, a nonspecific NOS inhibitor, at inhibiting LPSinduced NO production (Table 5). The remaining compounds, except for 20, inhibited NOS activity with $\mathrm{IC}_{50}$ values ranging from 6.3 to $22.3 \mu \mathrm{M}$ (Table 5). NOX is the major ROSproducing enzyme in activated inflammatory cells. 18 We previously reported that drugs with anti-inflammatory activity also show potent NOX-inhibitory action.19,20 Therefore, we evaluated the isolates for effects on NOX activity in lysates of microglial cells and PMN. Our data suggest that none of the tested compounds were potent inhibitors of NOX in lysates of microglial cells and PMN, relative to the specific NOX inhibitor diphenyleneiodonium (DPI) ( IC $_{50} 0.4$ and $0.3 \mu \mathrm{M}$, respectively) (Table 5). In addition, the free radical-scavenging capacities of these compounds were examined in a cell-free 1,1-diphenyl-2-picrylhydrazyl (DPPH) solution. None of the tested compounds showed significant free radical-scavenging activity.

Although it is now clear that proliferation of cells alone does not cause cancer, sustained cell proliferation in an environment rich in inflammatory cells, growth factors, activated stroma, and DNA-damage-promoting agents, certainly potentiates and/or promotes neoplastic risk. 21 In many circumstances, inflammation orchestrates the microenvironment around tumors, contributing to proliferation, survival, and migration. Cancer cells also use selectins, chemokines, and their receptors (involved in inflammatory response) for invasion, migration, and metastasis. Interestingly, Peng et al. found that a crude extract of Antrodia camphorata (Taiwanofungus camphoratus) significantly inhibited proliferation of three transitional cell carcinonoma (TCC) cell lines (RT4, a superficial cancer cell line and TSGH-8301, T24, two metastatic cancer cell lines), likely through different mechanisms.22 Combined with our observations in this study, it would be interesting to evaluate whether the antitumor invasion effect in the crude extract could be mediated through the antiinflammatory properties of the contained triterpenoids. Thus, the newly identified camphoratin analogs with both potent cytotoxicity and anti-inflammatory activity merit further investigation as cancer chemotherapeutic agents or as anti-inflammatory drugs for the treatment of NO-dependent neurodegenerative disorders. 


\section{Experimental Section}

\section{General Experimental Procedures}

Melting points were determined on a Yanagimoto MP-S3 micro-melting point apparatus. IR spectra were recorded on a Shimazu Prestige-21 FTIR spectrometer. Optical rotations were measured using a Jasco DIP-370 Polarimeter. UV spectra were obtained on a Hitachi UV-3210 spectrophotometer. ESI and HRESI mass spectra were recorded on a Bruker APEX II mass spectrometer. The NMR spectra, including ${ }^{1} \mathrm{H} N M R,{ }^{13} \mathrm{C} N M R, C O S Y$, NOESY, HMBC, and HMQC experiments, were recorded on Bruker AVANCE-500 and AMX-400. Silica gel (E. Merck 70-230, 230-400 mesh) was used for column chromatography.

\section{Fungal Material}

Wild fruiting bodies of $T$. camphoratus, which grew in Ping-Tung County, Taiwan, were purchased from the Kaohsiung Society for Wildlife and Nature in 2003. The fungus was identified by Dr. Tun-Tschu Chang (Taiwan Forestry Research Institute). A voucher specimen (TSWu 2003005) was deposited in the Department of Chemistry, National Cheng Kung University, Tainan, Taiwan.

\section{Extraction and Isolation}

The fruiting body of $T$. camphoratus $(1.0 \mathrm{~kg})$ was extracted with EtOH $(4 \times 10 \mathrm{~L})$ under reflux for $8 \mathrm{~h}$. The EtOH extract was concentrated to afford a brown syrup (161 g) and then partitioned between $\mathrm{H}_{2} \mathrm{O}$ and $n$-hexane. The $n$-hexane layer $(9.3 \mathrm{~g})$ was chromatographed on silica gel and eluted with EtOAc in $n$-hexane (0-100\% of EtOAc, gradient) to obtain 10 fractions. Fraction 4 was rechromatographed on a silica gel column using $n$-hexane- $\mathrm{Me}_{2} \mathrm{CO}$ (19:1) as eluent to yield $\mathbf{8}(3.0 \mathrm{mg}), \mathbf{9}(6.0 \mathrm{mg}), \mathbf{1 0}(4.5 \mathrm{mg}), \mathbf{1 9}(22.0 \mathrm{mg}), \mathbf{2 0}(90.2 \mathrm{mg}), \mathbf{2 1}$ $(22.1 \mathrm{mg})$, and $22(16.5 \mathrm{mg})$. Compound $22(41.1 \mathrm{mg})$ was obtained in the same way from fraction 8 . The water layer $(145 \mathrm{~g})$ was filtered and concentrated under reduced pressure to give a brown syrup $(55 \mathrm{~g})$ and a water-insoluble portion $(89 \mathrm{~g})$. The water-insoluble portion was chromatographed on a silica gel column using $\mathrm{CHCl}_{3}-\mathrm{MeOH}$ mixtures of increasing polarity for elution to obtain 10 fractions (WI-1-WI-10). Compounds $\mathbf{1}(2.2 \mathrm{mg}), \mathbf{5}(2.0 \mathrm{mg})$, $\mathbf{6}(14.2 \mathrm{mg}), \mathbf{9}(1.0 \mathrm{mg}), \mathbf{1 4}(1.29 \mathrm{~g}), \mathbf{1 5}(53.8 \mathrm{mg})$, and $\mathbf{2 1}(62.2 \mathrm{mg})$ were obtained from a combined fraction (fractions WI-1 and WI-2) by silica gel column chromatography with gradient elution $\left(\mathrm{CHCl}_{3}-\mathrm{Me}_{2} \mathrm{CO}, 39: 1\right.$ to 14:1). Fraction WI-3 was separated on a silica gel column using $i-\mathrm{Pr}_{2} \mathrm{O}-\mathrm{MeOH}(19: 1)$ as the eluent to yield $\mathbf{1 1}(141.5 \mathrm{mg}), \mathbf{1 8}(11.0 \mathrm{mg}), \mathbf{1 6}$ $(122.9 \mathrm{mg})$, and $\mathbf{1 2}(53.0 \mathrm{mg})$. Fraction WI-4 was chromatographed on a silica gel column with $i-\mathrm{Pr}_{2} \mathrm{O}-\mathrm{MeOH}$ (12:1) to give $\mathbf{7}(11.3 \mathrm{mg}), \mathbf{1 8}(38.0 \mathrm{mg}), \mathbf{1 6}(708.0 \mathrm{mg})$, and $\mathbf{1 2}$ (66.5 $\mathrm{mg})$. Compounds $2(5.0 \mathrm{mg}), \mathbf{4}(2.2 \mathrm{mg}), \mathbf{7}(3.4 \mathrm{mg})$, and $\mathbf{1 3}(286.2 \mathrm{mg})$ were obtained from fraction WI-5 using silica gel column chromatography (eluent, $\mathrm{CHCl}_{3}-\mathrm{MeOH}, 12: 1$ ). Fractions WI-6 and WI-7 were combined and rechromatographed on a silica gel column with $\mathrm{CHCl}_{3}-\mathrm{MeOH}(6: 1)$ as the mobile phase to afford $\mathbf{3}(3.8 \mathrm{mg})$ and $\mathbf{1 3}(1.81 \mathrm{~g})$. Compound $17(1.16 \mathrm{~g})$ was isolated from a combined fraction (fractions WI-8 and WI-9) by silica gel column chromatography using $i-\mathrm{Pr}_{2} \mathrm{O}-\mathrm{MeOH}(4: 1)$ as the eluent.

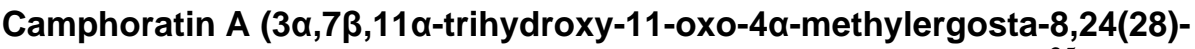
dien-26-oic acid, 1)—colorless powder $(\mathrm{MeOH}) ; \mathrm{mp} 117-119^{\circ} \mathrm{C} ;[\alpha]_{\mathrm{D}}{ }^{25}+221(c 0.001$, $\mathrm{MeOH}) ; \mathrm{UV}(\mathrm{MeOH}) \lambda_{\max }(\log \varepsilon) 255$ (3.49) nm; IR (KBr) $v_{\max }$ 3408, 2959, 2930, 2875, $1709,1660,1215,1059 \mathrm{~cm}^{-1} ;{ }^{1} \mathrm{H}$ NMR and ${ }^{13} \mathrm{C}$ NMR, see Table 1 and 2; ESIMS $\mathrm{m} / z 511$ $[\mathrm{M}+\mathrm{Na}]^{+}$; HRESIMS m/z 511.3038 (calcd for $\mathrm{C}_{29} \mathrm{H}_{44} \mathrm{O}_{6} \mathrm{Na} 511.3035$ ).

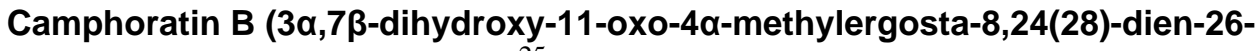
oic acid, 2)—colorless syrup; $[\alpha]_{\mathrm{D}}{ }^{25}+54(c 0.006, \mathrm{MeOH}) ; \mathrm{UV}(\mathrm{MeOH}) \lambda_{\max }(\log \varepsilon) 255$ 
(3.79) nm; IR (KBr) $v_{\max } 3420,2962,2935,2878,1709,1659,1217,1083 \mathrm{~cm}^{-1} ;{ }^{1} \mathrm{H}$ NMR and ${ }^{13} \mathrm{C}$ NMR, see Table 1 and 2; ESIMS $m / z 495[\mathrm{M}+\mathrm{Na}]^{+}$; HRESIMS $m / z 495.3089$ (calcd for $\mathrm{C}_{29} \mathrm{H}_{44} \mathrm{O}_{5} \mathrm{Na}$ 495.3086).

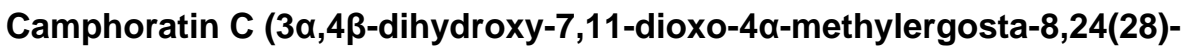
dien-26-oic acid, 3)-colorless powder $(\mathrm{MeOH}) ; \mathrm{mp} 186-188^{\circ} \mathrm{C}$; $[\alpha]_{\mathrm{D}}{ }^{25}+57(c 0.067$, $\mathrm{MeOH}) ; \mathrm{UV}(\mathrm{MeOH}) \lambda_{\max }(\log \varepsilon) 271(3.80) \mathrm{nm}$; IR (KBr) $v_{\max } 3411,2966,2936,2878$, 1709, 1674, 1230, $1062 \mathrm{~cm}^{-1} ;{ }^{1} \mathrm{H}$ NMR and ${ }^{13} \mathrm{C}$ NMR, see Table 1 and 2; ESIMS $\mathrm{m} / z 509$ $[\mathrm{M}+\mathrm{Na}]^{+}$; HRESIMS $\mathrm{m} / z$ 509.2874 (calcd for $\mathrm{C}_{29} \mathrm{H}_{42} \mathrm{O}_{6} \mathrm{Na} 509.2879$ ).

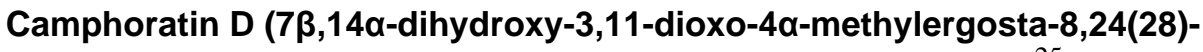
dien-26-oic acid 4)-colorless powder $(\mathrm{MeOH}) ; \mathrm{mp} 175-177^{\circ} \mathrm{C} ;[\alpha]_{\mathrm{D}}{ }^{25}+34^{\circ}(c 0.004$ $\mathrm{MeOH}) ; \mathrm{UV}(\mathrm{MeOH}) \lambda_{\max }(\log \varepsilon) 246(3.97) \mathrm{nm}$; IR (KBr) $v_{\max } 3444,2971,2936,2878$, 1708, 1670, 1229, 1187, 1068, $\mathrm{cm}^{-1} ;{ }^{1} \mathrm{H}$ NMR and ${ }^{13} \mathrm{C}$ NMR, see Table 1 and 3; ESIMS $\mathrm{m} /$ $z 509[\mathrm{M}+\mathrm{Na}]^{+}$; HRESIMS $m / z 509.2875$ (calcd for $\mathrm{C}_{29} \mathrm{H}_{42} \mathrm{O}_{6} \mathrm{Na} 509.2879$ ).

Camphoratin E (methyl 3a-hydroxy-7,11-dioxo-4a-methylergosta-8,24(28)dien-26-oate, 5)—colorless syrup; $[\alpha]_{\mathrm{D}}{ }^{25}+166$ ( $c$ 0.007, $\left.\mathrm{MeOH}\right) ; \mathrm{UV}(\mathrm{MeOH}) \lambda_{\max }$ $(\log \varepsilon) 260(3.68) \mathrm{nm} ; \mathrm{IR}(\mathrm{KBr}) v_{\max } 3491,2959,2936,2877,1730,1678,1235,1202,1169$ $\mathrm{cm}^{-1}$; ${ }^{1} \mathrm{H}$ NMR and ${ }^{13} \mathrm{C}$ NMR, see Table 1 and 3; ESIMS $m / z, 507[\mathrm{M}+\mathrm{Na}]^{+}$; HRESIMS $\mathrm{m} / \mathrm{z} 507.3088$ (calcd for $\mathrm{C}_{30} \mathrm{H}_{44} \mathrm{O}_{5} \mathrm{Na}$ 507.3086).

Camphoratin F (methyl 7 $\beta$-hydroxy-3,11-dioxo-4 $\alpha$-methylergosta-8,24(28)dien-26-oate, 6)-colorless powder (MeOH); mp 100-101 ${ }^{\circ} \mathrm{C}$; $[\alpha]_{\mathrm{D}}{ }^{25}+174(c 0.008$, $\mathrm{MeOH}) ; \mathrm{UV}(\mathrm{MeOH}) \lambda_{\max }(\log \varepsilon) 251$ (4.05) nm; IR (KBr) $v_{\max }$ 3386, 2967, 2877, 1732, 1711, 1669, 1235, 1197, 1167, $1083 \mathrm{~cm}^{-1} ;{ }^{1} \mathrm{H}$ NMR and ${ }^{13} \mathrm{C}$ NMR, see Table 1 and 3; ESIMS $m / z 507[\mathrm{M}+\mathrm{Na}]^{+} ;$HRESIMS m/z 507.3083 (calcd for $\mathrm{C}_{30} \mathrm{H}_{44} \mathrm{O}_{5} \mathrm{Na}$ 507.3086)

Camphoratin G (7a-hydroxy-3,11-dioxo-4a-methylergosta-8,24(28)-dien-26-oic acid, 7)—colorless powder (MeOH); mp 196-198 ${ }^{\circ} \mathrm{C}$; $[\alpha]_{\mathrm{D}}{ }^{25}+139$ (c 0.007, $\left.\mathrm{MeOH}\right)$; UV (MeOH) $\lambda_{\max }(\log \varepsilon) 247$ (4.33) nm; IR (KBr) $v_{\max }$ 3420, 2964, 2930, 2875, 1707, 1659, $1171 \mathrm{~cm}^{-1} ;{ }^{1} \mathrm{H}$ NMR and ${ }^{13} \mathrm{C}$ NMR, see Table 1 and 3; ESIMS $\mathrm{m} / z 493[\mathrm{M}+\mathrm{Na}]^{+}$; HRESIMS $m / z 493.2929$ (calcd for $\mathrm{C}_{29} \mathrm{H}_{42} \mathrm{O}_{5} \mathrm{Na}$ 493.2930).

Camphoratin H (4a-methylergosta-8,24(28)-dien-3,11-dione, 8)-colorless syrup; $[\alpha]_{\mathrm{D}} 25+41(c 0.008, \mathrm{MeOH}) ; \mathrm{UV}(\mathrm{MeOH}) \lambda_{\max }(\log \varepsilon) 248$ (3.94) nm; IR(KBr) $v_{\max } 2965$, 2940, 2877, 1711, $1678 \mathrm{~cm}^{-1}$; ${ }^{1} \mathrm{H}$ NMR and ${ }^{13} \mathrm{C}$ NMR, see Table 1 and 3; ESIMS $\mathrm{m} / z 447$ $[\mathrm{M}+\mathrm{Na}]^{+}$; HRESIMS $\mathrm{m} / z 447.3237$ (calcd for $\mathrm{C}_{29} \mathrm{H}_{44} \mathrm{O}_{2} \mathrm{Na} 447.3239$ ).

Camphoratin I [(25S)-26-hydroxy-ergosta-7,22-dien-3-one, 9]—colorless powder $(\mathrm{MeOH}) ; \mathrm{mp} 192-193{ }^{\circ} \mathrm{C} ;[\alpha]_{\mathrm{D}}{ }^{25}+128(c 0.003, \mathrm{MeOH}) ; \mathrm{IR}(\mathrm{KBr}) v_{\max } 3336,2956,2873$, 1716, $1024 \mathrm{~cm}^{-1}$; ${ }^{1} \mathrm{H}$ NMR and ${ }^{13} \mathrm{C}$ NMR, see Table 1 and 3; ESIMS $\mathrm{m} / z, 435[\mathrm{M}+\mathrm{Na}]^{+}$; HRESIMS $m / z$ 435.3242 (calcd for $\mathrm{C}_{28} \mathrm{H}_{44} \mathrm{O}_{2} \mathrm{Na} 435.3239$ ).

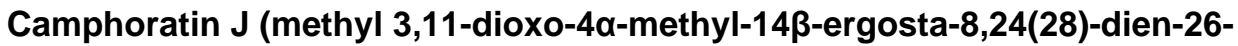
oate, 10)—colorless needles (MeOH); mp $100-102{ }^{\circ} \mathrm{C} ;[\alpha]_{\mathrm{D}}{ }^{25}+164(c 0.005, \mathrm{MeOH}) ; \mathrm{UV}$ $(\mathrm{MeOH}) \lambda_{\max }(\log \varepsilon) 250(4.35) \mathrm{nm}$; IR $(\mathrm{KBr}) v_{\max } 2953,2873,2856,1738,1709$, 1669,1460, 1453, 1375, $1077 \mathrm{~cm}^{-1} ;{ }^{1} \mathrm{H}$ NMR and ${ }^{13} \mathrm{C}$ NMR, see Table 1 and 3; ESIMS $\mathrm{m} / z$ $491[\mathrm{M}+\mathrm{Na}]^{+}$; HRESIMS m/z 491.3135 (calcd for $\mathrm{C}_{30} \mathrm{H}_{44} \mathrm{O}_{4} \mathrm{Na}$ 491.3137). 


\section{Preparation of $(R)$-MTPA Ester of 9}

To a solution of $9(0.5 \mathrm{mg})$ in pyridine $(0.4 \mathrm{~mL})$ was added $(S)$-MTPA chloride $(25 \mu \mathrm{L})$, and the mixture was allowed to stand for $3 \mathrm{~h}$ at room temperature. The reaction was quenched by the addition of $1.0 \mathrm{~mL}$ of $\mathrm{H}_{2} \mathrm{O}$, and the mixture was subsequently extracted with EtOAc ( $3 \times$ $1.0 \mathrm{~mL}$ ). The EtOAc-soluble layers were combined, dried over anhydrous $\mathrm{MgSO}_{4}$, and evaporated. The residue was subjected to silica gel column chromatography using $n$-hexaneEtOAc (4:1) as the eluent to yield the $(R)$-MTPA ester, 9a $(0.7 \mathrm{mg})$. Selective ${ }^{1} \mathrm{H}$ NMR (500 $\left.\mathrm{MHz}, \mathrm{CDCl}_{3}\right)$ of 9a: $\delta 7.38-7.53(5 \mathrm{H}, \mathrm{m}, \mathrm{Ph}), 5.21(1 \mathrm{H}, \mathrm{dd}, J=15.0,7.5 \mathrm{~Hz}, \mathrm{H}-23), 5.16$ $(1 \mathrm{H}, \mathrm{dd}, J=15.0,7.5 \mathrm{~Hz}, \mathrm{H}-22), 4.17$ ( $\left.2 \mathrm{H}, \mathrm{br} \mathrm{d}, J=6.4 \mathrm{~Hz}, \mathrm{H}_{2}-26\right), 3.54$ (3H, s, OMe), 1.02 $\left(3 \mathrm{H}, \mathrm{d}, J=6.5 \mathrm{~Hz}, \mathrm{H}_{3}-21\right), 1.01\left(3 \mathrm{H}, \mathrm{s}, \mathrm{H}_{3}-19\right), 0.95\left(3 \mathrm{H}, \mathrm{d}, J=7.0 \mathrm{~Hz}, \mathrm{H}_{3}-28\right), 0.85(3 \mathrm{H}, \mathrm{d}$, $\left.J=7.0 \mathrm{~Hz}, \mathrm{H}_{3}-27\right), 0.57\left(3 \mathrm{H}, \mathrm{s}, \mathrm{H}_{3}-18\right)$.

\section{In vitro Cytotoxicity Assay}

The KB-MDR cell line system was a generous gift from Professor Y.-C. Cheng, Yale University and was developed using step-wise vincristine selection as reported.23 The MDR cell-line KB-VIN and the parent KB nasopharyngeal were propagated in RPMI-1640 medium supplemented with $25 \mathrm{mM}$ HEPES, $10 \%$ fetal bovine serum, and $100 \mathrm{U} / \mathrm{mL}$ penicillin $\mathrm{G}, 100 \mu \mathrm{g} / \mathrm{mL}$ streptomycin, $250 \mathrm{ng} / \mathrm{mL}$ amphotericin B and cultured at $37^{\circ} \mathrm{C}$ in a humidified atmosphere of $95 \%$ air $/ 5 \% \mathrm{CO}_{2}$. KB-VIN cells were challenged with $0.5 \mu \mathrm{g} / \mathrm{mL}$ vincristine every two weeks and drug was removed at least one day prior to using the cells. For the anti-proliferation assay, trypsinized cells were seeded in 96-well microplates at densities of 5000 cells per well with compounds added from DMSO-diluted stock to give a dose-range of 20 down to $0.16 \mu \mathrm{M}$. After 3 days in culture, attached cells were fixed in situ with $10 \%$ trichloroacetic acid and then stained with $0.4 \%$ sulforhodamine B (SRB) in $1 \%$ HOAc. 24 The absorbance at $562 \mathrm{~nm}$ was measured using a microplate reader after solubilizing the bound dye. Results were plotted using Prizm software (GraphPad, San Diego CA). The mean $\mathrm{EC}_{50}$ is the concentration of agent interpolated from graphical results that caused a 50\% reduction in the cell number of treated versus untreated cells and is an average from at least two independent determinations; variation was less than 5\% of the mean.

\section{Microglial Cell Culture and Measurements of NO24}

The murine microglial cell line (BV2) was cultured in Dulbecco's modified Eagle medium (Gibco, USA) supplemented with 5\% fetal bovine serum (Hyclone). Production of NO was measured by the accumulation of nitrite in the culture medium $24 \mathrm{~h}$ after stimulation with LPS $(0.5 \mu \mathrm{g} / \mathrm{mL})$ by the Griess reagent. NO production was measured in the presence of $1-$ $50 \mu \mathrm{M}$ of test drugs. L-NAME (a non-selective NOS inhibitor) was included as a positive control. Data were calculated as 50\% inhibitory concentration $\left(\mathrm{IC}_{50}\right)$ and expressed as the mean \pm S.E.M. from 3-6 experiments performed on different days.

\section{Measurement of NOX Activity}

Activity was measured as ROS production triggered with NADPH $(200 \mu \mathrm{M})$ or fMLP (2 $\mu \mathrm{M})$ in the presence of $1-50 \mu \mathrm{M}$ of test drugs in BV2 cell lysate or PMN. DPI, a NOX inhibitor, was included as a positive control for NOX inhibition. Methodology was been previously described. 25

\section{Measurement of DPPH Radical-Scavenging Capacity}

DPPH radical-scavenging capacity assay was performed as in our previous report.19 Briefly, drugs were diluted in $\mathrm{MeOH}$ into a range of concentrations $(10-50 \mu \mathrm{M})$. DPPH solution $(200 \mu \mathrm{L} ; 200 \mu \mathrm{M}$ in $\mathrm{MeOH})$ was added to $10 \mu \mathrm{L}$ of each diluted sample in a 96-well microplate, and the resulting solution was allowed to react for $30 \mathrm{~min}$ in the dark at ambient 
temperature. The absorbance caused by the DPPH·radical at $517 \mathrm{~nm}$ was determined by a microplate-spectrophotometer. The radical scavenging capacity was expressed as delta $\mathrm{OD}_{517}\left(\Delta \mathrm{OD}_{517}\right)$, and values were the means of three replicates. Trolox, an antioxidant, was included as a reference.

\section{Supplementary Material}

Refer to Web version on PubMed Central for supplementary material.

\section{Acknowledgments}

The authors acknowledge Dr. Tun-Tschu Chang (Division of Forest Protection, Taiwan Forestry Research Institute, Taipei, Taiwan) for his identification and the financial support from the National Science Council, Taiwan, Republic of China awarded to T.-S. Wu. This investigation is supported in part by Taiwan Department of Health Cancer Research Center of Excellence (DOH99-TD-C-111-005) awarded to T.-S and also supported in part by grant CA-17625 from the National Cancer Institute, NIH, awarded to K.-H. Lee

\section{References and Notes}

1. Wu SH, Yu ZH, Dai YC, Chen CT, Su CH, Chen LC, Hsu WC, Hwang GY. Fung Sci. 2004; 19:109-116.

2. Tsai, ZT.; Liaw, SL. The Use and the Effect of Ganoderma. Sang-Yun Press; Taichung, Taiwan: 1982. p. 116

3. Shen YC, Wang YH, Chou YC, Chen CF, Lin LC, Chang TT, Tien JH, Chou CJ. Planta Med. 2004; 70:310-314. [PubMed: 15095145]

4. Chen CH, Yang SW, Shen YC. J Nat Prod. 1995; 58:1655-1661. [PubMed: 8594142]

5. Cherng IH, Chiang HC, Cheng MC, Wang Y. J Nat Prod. 1995; 58:365-371.

6. Shen CC, Kuo YC, Huang RL, Lin LC, Don MJ, Chang TT, Chou CJ. J Chin Med. 2003; 14:247258.

7. Cherng IW, Wu DP, Chiang HC. Phytochemistry. 1996; 41:263-267.

8. Shirane N, Takenaka H, Ueda K, Hashimoto Y, Katoh K, Ishii H. Phytochemistry. 1996; 41:13011308.

9. Abraham RJ, Monasterios JR. J Chem Soc, Perkin Trans. 1974; II:662-665.

10. Wu DP, Chiang HC. J Chin Chem Soc. 1995; 42:797-800.

11. Rösecke J, König WA. Phytochemistry. 2000; 54:757-762. [PubMed: 11014261]

12. Hu SH, Genain G, Azerad R. Steroids. 1995; 60:337-352. [PubMed: 8539788]

13. Rösecke J, König WA. Phytochemistry. 2000; 54:603-610. [PubMed: 10963454]

14. D’Auria MV, De Riccardis F, Minale L, Riccio R. J Chem Soc, Perkin Trans 1. 1990:2889-2893.

15. Fu X, Ferreira MLG, Schmitz FJ, Kelly M. J Org Chem. 1999; 64:6706-6709. [PubMed: 11674675]

16. Burgoyne DL, Andersen RJ, Allen TM. J Org Chem. 1992; 57:525-528.

17. Shoji N, Umeyama A, Shin K, Takeda K, Arihara S, Kobayashi J, Takei M. J Org Chem. 1992; 57:2996-2997.

18. Van den Worm E, Beukelman CJ, Van den Berg AJ, Kroes BH, Labadie RP, Van Dijk H. Eur J Pharmacol. 2001; 433:225-230. [PubMed: 11755156]

19. Lin LC, Wang YH, Hou YC, Chang S, Liou KT, Chou YC, Wang WY, Shen YC. J Pharm Pharmacol. 2006; 58:129-135. [PubMed: 16393473]

20. Liou KT, Shen YC, Chen CF, Tsao CM, Tsai SK. Eur J Pharmacol. 2003; 475:19-27. [PubMed: 12954355]

21. Coussens LM, Werb Z. Nature. 2002; 420:860-867. [PubMed: 12490959]

22. Peng CC, Chen KC, Peng RY, Chyau CC, Su CH, Hsieh-Li HM. J Ethnopharm. 2007; 109:93103. 
23. Ferguson PJ, Fisher MH, Stephenson J, Li DH, Zhou BS, Cheng YC. Cancer Res. 1988; 48:5956. [PubMed: 2844393]

24. Rubinstein LV, Shoemaker RH, Paull KD, Simon RM, Tosini S, Skehan P, Scudiero DA, Monks A, Boyd MR. J Nat Cancer Inst. 1990; 82:1113. [PubMed: 2359137]

25. Wang YH, Wang WY, Chang CC, Liou KT, Sung YJ, Liao JF, Chen CF, Chang S, Hou YC, Chou YC, Shen YC. J Biomed Sci. 2006; 13:127-141. [PubMed: 16283433] 


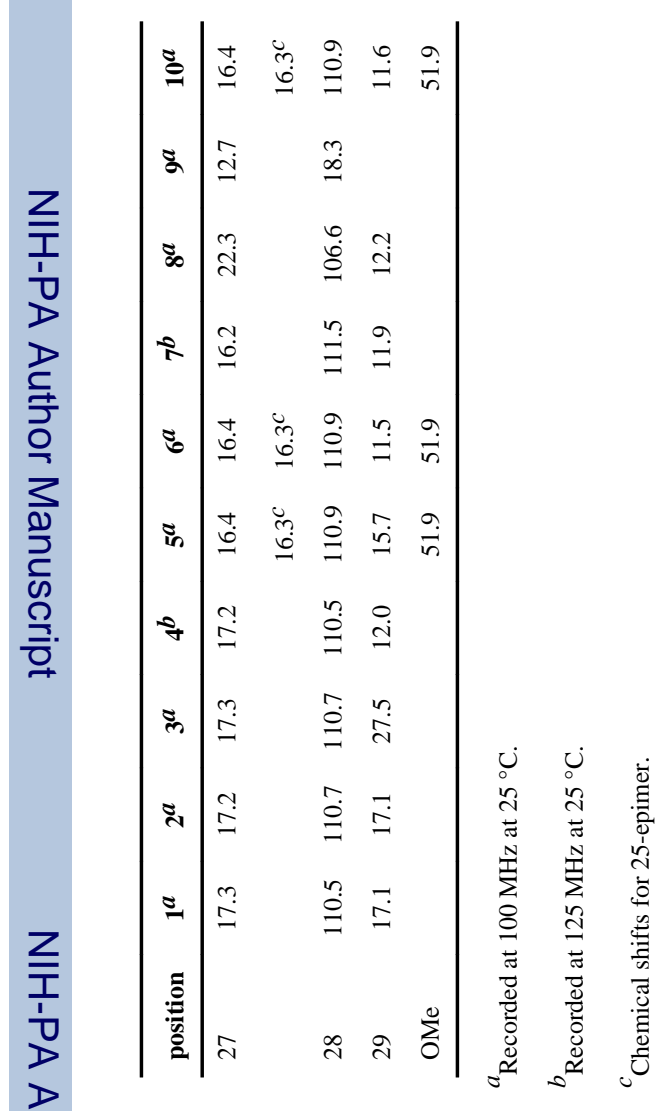


Table 2

${ }^{1} \mathrm{H}$ NMR Data for Compounds 1-4 (in Pyridine- $d_{5}$ )

\begin{tabular}{|c|c|c|c|c|}
\hline position & ${ }_{1}^{a}$ & $2^{a}$ & $3^{a}$ & $4^{b}$ \\
\hline \multirow[t]{2}{*}{1} & $1.93 \mathrm{~m}$ & $1.85 \mathrm{~m}$ & $2.10 \operatorname{td}(13.2,3.2)$ & $1.50 \mathrm{~m}$ \\
\hline & $2.78 \mathrm{~m}$ & $2.85 \mathrm{~m}$ & $3.04 \mathrm{dt}(13.2,3.2)$ & $3.28 \mathrm{~m}$ \\
\hline \multirow[t]{2}{*}{2} & $1.86 \mathrm{~m}$ & $1.86 \mathrm{~m}$ & $1.92 \mathrm{~m}$ & $2.40 \mathrm{~m}$ \\
\hline & $1.93 \mathrm{~m}$ & $1.89 \mathrm{~m}$ & $2.74 \mathrm{~m}$ & $2.52 \mathrm{~m}$ \\
\hline 3 & $3.89 \mathrm{~d}(1.6)^{c}$ & $3.91 \mathrm{~d}(2.4)$ & $4.02 \mathrm{br} \mathrm{s}$ & \\
\hline 4 & $1.64 \mathrm{~m}$ & $1.62 \mathrm{~m}$ & & $2.39 \mathrm{~m}$ \\
\hline 5 & $2.13 \mathrm{~m}$ & $2.02 \mathrm{~m}$ & $2.65 \mathrm{~m}$ & $1.50 \mathrm{~m}$ \\
\hline \multirow[t]{2}{*}{6} & $1.74 \mathrm{~m}$ & $1.67 \mathrm{~m}$ & $2.90 \mathrm{dd}(13.2,3.2)$ & $2.23 \mathrm{~m}$ \\
\hline & $2.42 \mathrm{~m}$ & $2.39 \mathrm{~m}$ & $3.14 \mathrm{t}(13.2)$ & $2.51 \mathrm{~m}$ \\
\hline 7 & $4.52 \mathrm{t}(8.4)$ & $4.50 \mathrm{t}(8.4)$ & & $4.98 \mathrm{t}(8.4)$ \\
\hline \multirow[t]{2}{*}{12} & $4.44 \mathrm{~s}$ & $2.43 \mathrm{~d}(13.2)$ & $2.46 \mathrm{~d}(13.2)$ & $2.74 \mathrm{~d}(15.8)$ \\
\hline & & $2.95 \mathrm{~d}(13.2)$ & $2.97 \mathrm{~d}(13.2)$ & $2.89 \mathrm{~d}(15.8)$ \\
\hline 14 & $3.57 \mathrm{dd}(12.0,6.8)$ & $2.66 \mathrm{dd}(12.0,6.0)$ & $2.67 \mathrm{~m}$ & \\
\hline \multirow[t]{2}{*}{15} & $2.19 \mathrm{~m}$ & $2.01 \mathrm{~m}$ & $1.66 \mathrm{~m}$ & $1.80 \mathrm{~m}$ \\
\hline & $2.50 \mathrm{~m}$ & $2.49 \mathrm{~m}$ & $2.74 \mathrm{~m}$ & \\
\hline \multirow[t]{2}{*}{16} & $1.42 \mathrm{~m}$ & 1.45 & 1.44 & $1.60 \mathrm{~m}$ \\
\hline & & & & $1.83 \mathrm{~m}$ \\
\hline 17 & $2.42 \mathrm{~m}$ & $1.43 \mathrm{~m}$ & $1.42 \mathrm{~m}$ & $1.75 \mathrm{~m}$ \\
\hline 18 & $0.90 \mathrm{~s}$ & $0.88 \mathrm{~s}$ & $0.72 \mathrm{~s}$ & $1.22 \mathrm{~s}$ \\
\hline 19 & $1.57 \mathrm{~s}$ & $1.49 \mathrm{~s}$ & $1.99 \mathrm{~s}$ & $1.45 \mathrm{~s}$ \\
\hline 20 & $1.41 \mathrm{~m}$ & $1.40 \mathrm{~m}$ & 1.38 & $1.56 \mathrm{~m}$ \\
\hline 21 & $1.11 \mathrm{~d}(7.6)$ & $0.89 \mathrm{~d}(7.6)$ & $0.87 \mathrm{~d}(5.2)$ & $1.01 \mathrm{~d}(6.5)$ \\
\hline \multirow[t]{4}{*}{22} & $1.37 \mathrm{~m}$ & $1.31 \mathrm{~m}$ & $1.30 \mathrm{~m}$ & $1.27 \mathrm{~m}$ \\
\hline & $1.81 \mathrm{~m}$ & $1.75 \mathrm{~m}$ & $1.75 \mathrm{~m}$ & $1.88 \mathrm{~m}$ \\
\hline & $2.25 \mathrm{~m}$ & $2.20 \mathrm{~m}$ & $2.20 \mathrm{~m}$ & $2.23 \mathrm{~m}$ \\
\hline & $2.44 \mathrm{~m}$ & $2.39 \mathrm{~m}$ & $2.38 \mathrm{~m}$ & $2.42 \mathrm{~m}$ \\
\hline 25 & $3.45 \mathrm{q}(6.8)$ & $3.45 \mathrm{q}(7.2)$ & $3.45 \mathrm{q}(7.2)$ & $3.44 \mathrm{q}(7.2)$ \\
\hline 27 & $1.48 \mathrm{~d}(7.2)$ & $1.49 \mathrm{~d}(6.8)$ & $1.49 \mathrm{~d}(7.2)$ & $1.47 \mathrm{~d}(7.2)$ \\
\hline \multirow[t]{2}{*}{28} & $5.07 \mathrm{~s}$ & $5.06 \mathrm{~s}$ & $5.06 \mathrm{~s}$ & $5.06 \mathrm{~s}$ \\
\hline & $5.23 \mathrm{~s}$ & $5.22 \mathrm{~s}$ & $5.23 \mathrm{~s}$ & $5.21 \mathrm{~s}$ \\
\hline 29 & $1.18 \mathrm{~d}(6.8)$ & $1.18 \mathrm{~d}(6.4)$ & $1.61 \mathrm{~s}$ & $1.11 \mathrm{~d}(6.6)$ \\
\hline
\end{tabular}

$a_{\text {Recorded at }} 400 \mathrm{MHz}$ at $25^{\circ} \mathrm{C}$.

${ }^{b}$ Recorded at $500 \mathrm{MHz}$ at $25^{\circ} \mathrm{C}$.

${ }^{c}{ }_{\text {values (in } \mathrm{Hz} \text { ) in parentheses. }}$ 


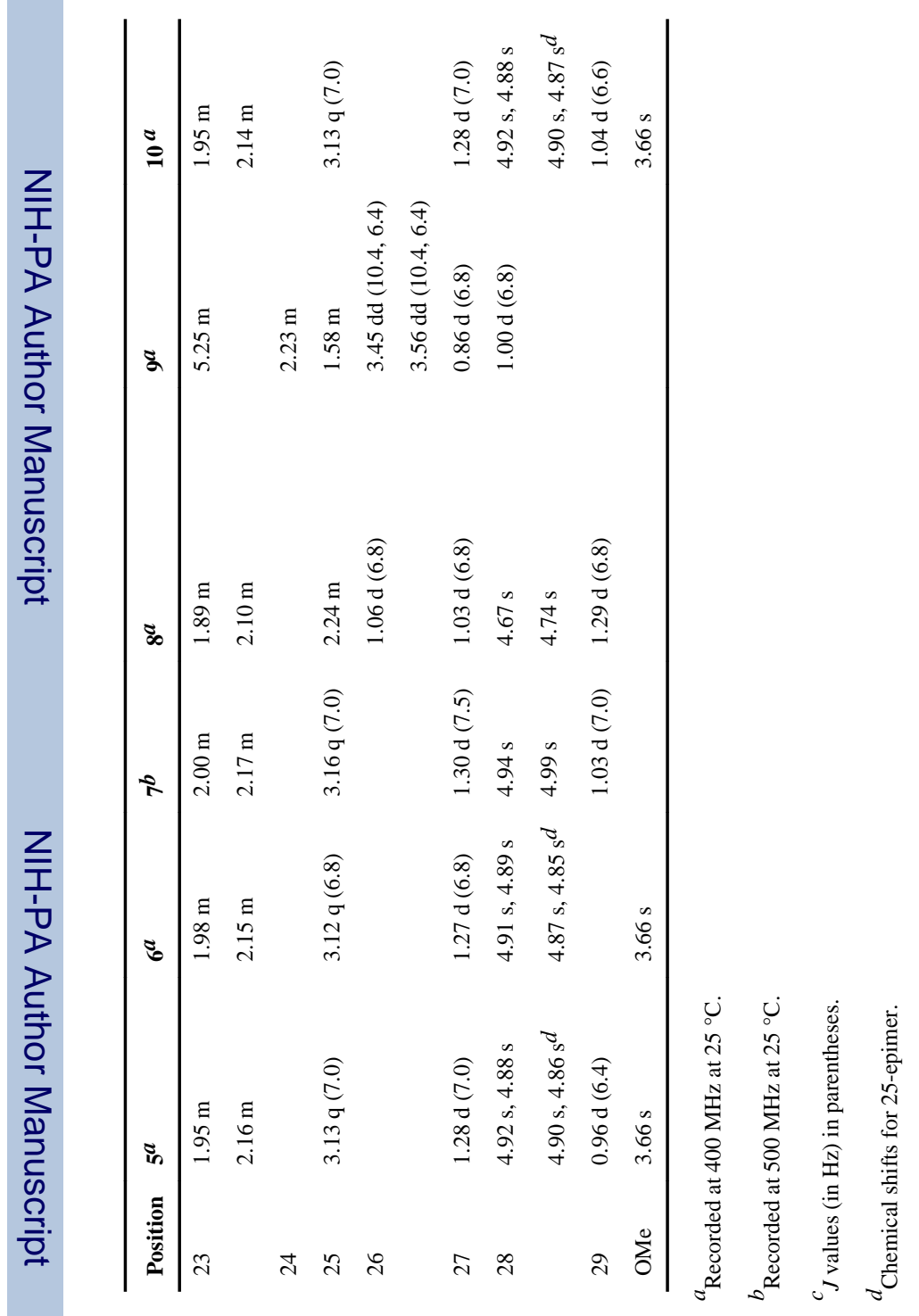


Table 4

In vitro Cytotoxicity of Compounds 1-19.

\begin{tabular}{|c|c|c|}
\hline \multirow{2}{*}{ Cmpd } & \multicolumn{2}{|c|}{$\mathrm{EC}_{50}(\mu \mathrm{M})$} \\
\hline & KB & KB-VIN \\
\hline 1 & $\mathrm{NA}^{a}$ & NA \\
\hline 2 & 1.8 & NA \\
\hline 3 & 0.3 & 2.3 \\
\hline 4 & 1.0 & 1.4 \\
\hline 5 & 0.45 & 2.7 \\
\hline 6 & 2.0 & 2.9 \\
\hline 7 & 15.0 & 17.5 \\
\hline 8 & NA & NA \\
\hline 9 & NA & NA \\
\hline 10 & NA & NA \\
\hline 11 & 3.0 & 6.2 \\
\hline 12 & 7.3 & 8.5 \\
\hline 13 & 15.5 & 6.4 \\
\hline 14 & $>20(21)^{b}$ & $>20(25)$ \\
\hline 15 & 4.9 & 10.0 \\
\hline 16 & NA & NA \\
\hline 17 & NA & NA \\
\hline 18 & NA & NA \\
\hline 19 & $>20(34)$ & $>20(18)$ \\
\hline etoposide & 4.5 & $>36$ \\
\hline
\end{tabular}

${ }^{a}$ NA; Not active. No growth inhibition at $20 \mu \mathrm{M}$.

${ }^{b}$ Values in parentheses are $\%$ inhibition at $20 \mu \mathrm{M}$. 
Table 5

Effects of Compounds 2, 6, 9, and 10-22 on NOX Activity ${ }^{a}$ in Murine Microglial Cells and PMN and on NOS Activity $^{b}$ in Murine Microglial Cells

\begin{tabular}{|c|c|c|c|}
\hline \multirow[b]{2}{*}{ Compound } & \multicolumn{2}{|c|}{$\mathrm{IC}_{50}(\mu \mathrm{M})$ in NOX } & \multirow[b]{2}{*}{$\mathrm{IC}_{50}(\mu \mathrm{M})$ in NOS } \\
\hline & activity from BV2 cell lysate & fMLP-induced NOX activation in PMN & \\
\hline 2 & NA & $32.1 \pm 3.5^{*}$ & $15.7 \pm 0.9^{*}$ \\
\hline 6 & NA & $11.2 \pm 2.3^{*}$ & $2.5 \pm 0.6^{*}$ \\
\hline 9 & NA & $17.5 \pm 3.9^{*}$ & $12.7 \pm 2.2^{*}$ \\
\hline 10 & NA & $15.8 \pm 4.0^{*}$ & $1.6 \pm 0.6^{*}$ \\
\hline 11 & NA & $22.1 \pm 6.7^{*}$ & $3.6 \pm 0.8^{*}$ \\
\hline 12 & NA & NA & $9.6 \pm 0.7^{*}$ \\
\hline 13 & $40.3 \pm 3.5^{*}$ & NA & $16.2 \pm 0.9^{*}$ \\
\hline 14 & NA & $8.4 \pm 2.1^{*}$ & $0.6 \pm 0.3^{*}$ \\
\hline 15 & $45.9 \pm 7.9^{*}$ & $29.2 \pm 6.7^{*}$ & $4.1 \pm 0.5^{*}$ \\
\hline 16 & NA & $22.6 \pm 3.3^{*}$ & $4.2 \pm 1.2^{*}$ \\
\hline 17 & NA & $47.2 \pm 8.4^{*}$ & NA \\
\hline 18 & $16.0 \pm 8.1^{*}$ & $18.1 \pm 5.9^{*}$ & $2.5 \pm 0.3^{*}$ \\
\hline 19 & NA & $21.9 \pm 6.3^{*}$ & $22.3 \pm 2.9^{*}$ \\
\hline 20 & NA & $27.9 \pm 5.6^{*}$ & $30.6 \pm 0.8^{*}$ \\
\hline 21 & NA & $16.2 \pm 4.3^{*}$ & $1.5 \pm 0.7^{*}$ \\
\hline 22 & NA & $20.3 \pm 6.4^{*}$ & $6.3 \pm 1.8^{*}$ \\
\hline DPI & $0.4 \pm 0.2$ & $0.3 \pm 0.1$ & - \\
\hline L-NAME & - & - & $25.8 \pm 2.5$ \\
\hline
\end{tabular}

${ }^{a}$ NOX activity was measured as ROS production triggered with NADPH (200 $\left.\mu \mathrm{M}\right)$ or fMLP $(2 \mu \mathrm{M})$ in the presence of $1-50 \mu \mathrm{M}$ of test drugs in BV2 cell lysate or peripheral human neutrophils (PMN). DPI, a NOX inhibitor, was included as a positive control for NOX inhibition.

${ }^{b}$ NO production was measured in the presence of 1-50 $\mu \mathrm{M}$ of test drugs. L-NAME (a non-selective NOS inhibitor) was included as a positive control. Data were calculated as 50\% inhibitory concentration (IC50) and expressed as the mean \pm S.E.M. from 3-6 experiments performed on different days using BV2 cell lysate or PMN from different passages or donors. NA: not active."-": samples not tested

P $<0.05$ as compared with relative positive control, respectively. 